Jurnal Qua Teknika, Vol. 6 No. 1 Maret 2016

p ISSN: 2088 2424; e ISSN: 2527 3892

UNISBA Blitar, Http://qua.unisbablitar.ejournal.web.id

M. Nur Rois Zain. 2016. Sistem Pengaman Pendingin Udara Tiga Fasa Otomatis dalam Mengantisipasi

Gangguan. Jurnal Qua Teknika, (2016), 6(1):1 15.

\title{
SISTEM PENGAMAN PENDINGIN UDARA TIGA FASA OTOMATIS DALAM MENGANTISIPASI GANGGUAN
}

\author{
M.Nur Rois Zain \\ Universitas Brawijaya \\ Jln. MT. Haryono, Malang
}

Penelitian dengan membuat alat pengaman air conditioning tiga fasa secara elektronik ini memiliki beberapa tujuan, antara lain : Mengetahui unjuk kerja alat pengaman air conditioning tiga fasa secara elektronik Terhadap Gangguan beban lebih (over load), Gangguan tegangan lebih (over voltage), Gangguan tegangan kurang (under voltage), Gangguan kegagalan fasa (phase failure), Gangguan fasa terbalik (reversing of phase),Serta Mengetahui Seberapa besar kepekaan alat dalam bekerja memutus tegangan sumber jika terjadi gangguan

Kata Kunci: Air Conditioner, Gangguan, Tegangan, tiga fasa

\section{PENDAHULUAN}

Pada sistem tenaga listrik tiga fasa, daya yang dibangkitkan, disalurkan dan didistribusikan menggunakan sistem yang seimbang. Jumlah daya yang diserap oleh beban listrik tiga fasa diperoleh dengan menjumlahkan daya dari tiap - tiap fasanya. Pada sistem yang seimbang, daya total tersebut sama dengan tiga kali daya pada satu fasanya, dengan asumsi daya pada tiap fasa sama, tapi itu berdasarkan teori, secara kenyataan mesin - mesin listrik yang mengkonsumsi daya berbeda - beda tiap fasanya tergantung pada kondisi dari mesin listriknya.

Semakin baik mesin listrik tersebut maka konsumsi daya tiap fasanya hampir sama sehingga mesin listrik tersebut dapat bekerja secara maksimal tiap fasanya. Sebagai contoh, mesin Air Conditioning tiga fasa menyerap arus pada fasa $\mathrm{R}=20 \mathrm{~A} ; \mathrm{S}=19,5 \mathrm{~A} ; \mathrm{T}=20,25 \mathrm{~A}$. Ini menandakan kondisi mesin masih baik, sehingga menyerap energi listrik yang hampir seimbang, sehingga mesin bekerja secara optimal. Contoh lain, AC menyerap arus pada fasa $\mathrm{R}$ $=23 \mathrm{~A} ; \mathrm{S}=17 \mathrm{~A} ; \mathrm{T}=19 \mathrm{~A}$. Jelas terlihat bahwa selisih konsumsi arus sangat besar, sehingga ada fasa yang sudah bekerja maksimal, tapi ada fasa yang bekerja kurang optimal, apabila dibebani yang lebih besar lagi maka fasa yang mengkonsumsi arus yang lebih besar, dan dapat membahayakan mesin tersebut.

Selain gangguan yang berasal dari mesin, terdapat pula gangguan - gangguan yang berasal dari luar yang menyebabkan sistem tenaga listrik tiga fasa menjadi terganggu. Gangguan - gangguan tersebut dapat diakibatkan oleh hubung singkat, penghantar penghantar yang terbuka atau kegagalan fasa, perubahan suplai tegangan, dan perbedaan suplai tegangan tiap fasa. Dipandang dari sisi keselamatan kerja dan keandalan sistem pada peralatan yang menggunakan sistem tenaga listrik tiga fasa, maka sangat diperlukan pengamanan peralatan tiga fasa dari gangguan - gangguan tersebut.

Berkaitan dengan agar peralatan air conditioning tiga fasa dapat bekerja dengan optimal dan terlindung dari berbagai gangguan maka sangat diperlukan pengkajian suatu alat pengaman yang dapat mengkompensasi bahwa peralatan selalu mendapatkan suplai tegangan yang seimbang sekaligus mampu mengidentifikasi kondisi membahayakan dan mengamankan 
Jurnal Qua Teknika, Vol. 6 No. 1 Maret 2016

p ISSN: 2088 2424; e ISSN: 2527 3892

UNISBA Blitar, Http:// qua.unisbablitar.ejournal.web.id

M. Nur Rois Zain. 2016. Sistem Pengaman Pendingin Udara Tiga Fasa Otomatis dalam Mengantisipasi Gangguan. Jurnal Qua Teknika, (2016), 6(1):1 15.

peralatan yang dilindunginya. Pengkajian ini dipandang perlu karena selama ini pengaman beban tiga fasa yang ada hanya mampu mendeteksi keseimbangan suplai tegangan, dan mendeteksi arus lebih secara terpisah.

Penulis merancang sebuah alat pengaman yang mampu mendeteksi keseimbangan suplai tegangan, kegagalan fasa, ketidakseimbangan arus beban, arus lebih, tegangan lebih dan tegangan kurang. Prinsip alat pengaman ini adalah membandingkan besarnya arus beban yang mengalir pada tiap fasa.

Penelitian dengan membuat alat pengaman air conditioning tiga fasa secara elektronik ini memiliki beberapa tujuan, antara lain :

1. Mengetahui unjuk kerja alat pengaman air conditioning tiga fasa secara elektronik.

2. Untuk menciptakan alat - alat baru berkaitan dengan proteksi pada sistem tenaga listrik tiga fasa, dalam rangka peningkatan keamanan dan keandalan sistem.

\section{METODE}

Metode penelitian ini adalah eksperimen, yang sesuai dengan tujuan penelitian yaitu perencanaan dan membuat suatu alat. Sasaran penelitian ini adalah pada perencanaan dan pembuatan alat pengaman air conditioning tiga fasa secara elektronik. Selanjutnya hasil rancangan diuji coba dengan alat - alat laboratorium.

Salah satu langkah yang terpenting dalam penelitian adalah alat pengumpul data. Alat pengumpul data sering disebut dengan instrumen penelitian. Instrumen penelitian ini berguna untuk memperoleh data dengan jalan melakukan pengukuran. Adapun peralatan yang digunakan sebagai alat instrumen dalam penelitian ini antara lain multimeter SANWA YX360TRF, digital AC clamp meter KYORITSU model 2007A dengan akurasi pada $400 \mathrm{~A} \pm$ $1,5 \%$ rdg \pm 4 dgt, dan second meter.

Data dalam penelitian ini diperoleh dengan metode eksperimen terhadap subyek yang diteliti. Teknik pengumpulan datanya adalah dengan pengamatan langsung dengan alat ukur (instrumen penelitian). Pengamatan merupakan pengukuran secara langsung terhadap suatu besaran dengan menggunakan alat ukur. Hasil pengukuran inilah yang kemudian diambil sebagai data dalam penelitian.

Data yang diperoleh kemudian disajikan dalam bentuk tabel dan grafik. Tabel - tabel dalam penelitian ini dibuat ke dalam beberapa bentuk, seperti ditunjukkan pada tabel 1, 2, 3, 4, dan 5. pengukuran dilakukan pada beban 0,89 ampere, 1,27 ampere, 1,73 ampere dan 2,1 ampere.

Pengambilan data untuk setiap percobaan dilakukan selama lima kali (replikasi), untuk kemudian diambil nilai rata - ratanya dengan persamaan 32 .

$$
\bar{X}=\frac{X_{1}+X_{2}+X_{3}+\ldots+X_{n}}{n}
$$

Ket : $X=$ Nilai rata - rata

$\mathrm{X}=$ Nilai pengukuran $\mathrm{ke}-\mathrm{n}$

$\mathrm{n}=$ Jumlah pengukuran

Analisis data yang digunakan adalah analisis deskriptif. Analisis deskriptif adalah analisis data dengan cara mendeskriptifkan atau menggambarkan data yang telah terkumpul 
Jurnal Qua Teknika, Vol. 6 No. 1 Maret 2016

p ISSN: 2088 2424; e ISSN: 2527 3892

UNISBA Blitar, Http:// qua.unisbablitar.ejournal.web.id

M. Nur Rois Zain. 2016. Sistem Pengaman Pendingin Udara Tiga Fasa Otomatis dalam Mengantisipasi Gangguan. Jurnal Qua Teknika, (2016), 6(1):1 15.

sebagaimana adanya, tanpa bermaksud membuat kesimpulan yang berlaku untuk umum atau generalisasi.

Deskriptis adalah metode menjelaskan data dengan cara merangkum dan meringkas yang disajikan dalam bentuk tabel data, gambar grafik dan distribusi frekwensi.

\section{HASIL DAN PEMBAHASAN}

Seperti yang telah dikemukakan sebelumnya bahwa penelitian ini bertujuan untuk mengetahui unjuk kerja alat pengaman air conditioning tiga fasa secara elektronis.

Obyek dalam penelitian ini adalah alat pengaman air conditioning tiga fasa secara elektronis. Metode pengambilan data dilakukan dengan cara percobaan - percobaan, dari setiap percobaan dilakukan pengukuran - pengukuran. Percobaan yang dilakukan adalah memberikan beberapa jenis gangguan pada alat pengaman tersebut. Hasil pengukuran selengkapnya dapat dilihat pada tabel data terlampir.

Deskripsi data berikut ini akan menyajikan data hasil pengukuran pada masing - masing percobaan dalam bentuk tabel. Percobaan tersebut terdiri atas percobaan gangguan arus lebih, gangguan percobaan tegangan lebih, percobaan gangguan tegangan kurang, percobaan gangguan kegagalan fasa, percobaan gangguan fasa terbalik, percobaan respon waktu alat pengaman terhadap masing - masing gangguan diatas.

\section{Gangguan arus lebih (overload fault)}

Percobaan yang dilakukan dengan memberikan gangguan berupa perubahan arus beban pada salah satu fasanya, pada kedua fasanya dan pada ketiga fasanya. Arus gangguan diatur dengan menambah beban pada fasa yang mendapat gangguan sehingga arus beban pada fasa yang di tambah menjadi lebih besar dibandingkan dengan fasa yang lainnya. Data hasil pengukuran dapat dilihat seperti pada tabel. Pengukuran dilakukan pada sistem tegangan tiga fasa 220 / 380 volt. Alat ini mendeteksi besarnya arus yang mengalir, untuk itu saat pengukuran dipasang beban tiga fasa seimbang. Beban terpasang saat pengukuran adalah 1 ampere, 2 ampere, dan 3 ampere. Hasil percobaan ditunjukkan pada tabel IV.1, IV.2 dan IV.3.

\section{Tabel IV.1. Data hasil unjuk kerja alat terhadap gangguan arus lebih pada salah satu fasa}


Jurnal Qua Teknika, Vol. 6 No. 1 Maret 2016

p ISSN: 2088 2424; e ISSN: 2527 3892

UNISBA Blitar, Http: / qua.unisbablitar.ejournal.web.id

M. Nur Rois Zain. 2016. Sistem Pengaman Pendingin Udara Tiga Fasa Otomatis dalam Mengantisipasi Gangguan. Jurnal Qua Teknika, (2016), 6(1):1 15.

\begin{tabular}{|c|c|c|c|c|c|}
\hline \multirow{2}{*}{ Arus Beban (A) } & \multicolumn{3}{|c|}{$\begin{array}{c}\text { Arus lebih }(A) \\
\text { (25\% arus beban) }\end{array}$} & \multicolumn{2}{|c|}{ Kondisi } \\
\hline & Fasa $\mathbf{R}$ & Fasa S & Fasa $T$ & Kerja & Tidak \\
\hline 0,89 & 0.22 & & & $\checkmark$ & \\
\hline 1,27 & 0,32 & & & $\sqrt{ }$ & \\
\hline 1,73 & 0,43 & & & $\checkmark$ & \\
\hline 2,1 & 0.53 & & & $\sqrt{ }$ & \\
\hline 0,89 & & 0.22 & & $\sqrt{ }$ & \\
\hline 1,27 & & 0,32 & & $\sqrt{ }$ & \\
\hline 1,73 & & 0,43 & & $d$ & \\
\hline 2,1 & & 0.53 & & $\sqrt{ }$ & \\
\hline 0,89 & & & 0,22 & $\sqrt{ }$ & \\
\hline 1,27 & & & 0.32 & $\sqrt{ }$ & \\
\hline 1,73 & & & 0,43 & $\sqrt{ }$ & \\
\hline 2,1 & & & 0.53 & $\sqrt{ }$ & \\
\hline
\end{tabular}

Tabel IV.2. Data hasil unjuk kerja alat terhadap gangguan arus lebih pada kedua fasa

\begin{tabular}{|c|c|c|c|c|c|}
\hline \multirow[t]{2}{*}{ Beban $(\boldsymbol{A})$} & \multicolumn{3}{|c|}{$\begin{array}{c}\text { Arus lebih }(A) \\
(25 \% \text { arus beban) }\end{array}$} & \multicolumn{2}{|c|}{ Kondisi } \\
\hline & Fasa R & Fasa S & Fasa T & Kerja & Tidak \\
\hline 0,89 & 0,22 & 0,22 & & $\checkmark$ & \\
\hline 1.27 & 0,32 & 0.32 & & $\checkmark$ & \\
\hline 1,73 & 0,43 & 0.43 & & $\sqrt{ }$ & \\
\hline 2,1 & 0.53 & 0.53 & & $\sqrt{ }$ & \\
\hline 0,89 & & 0.22 & 0,22 & $\checkmark$ & \\
\hline 1,27 & & 0,32 & 0,32 & $\sqrt{ }$ & \\
\hline 1,73 & & 0,43 & 0,43 & $\sqrt{ }$ & \\
\hline 2,1 & & 0.53 & 0.53 & $\sqrt{ }$ & \\
\hline 0,89 & 0,22 & & 0,22 & $\checkmark$ & \\
\hline 1,27 & 0,32 & & 0,32 & $\checkmark$ & \\
\hline 1.73 & 0.43 & & 0,43 & $\sqrt{ }$ & \\
\hline 2.1 & 0.53 & & 0.53 & $\sqrt{ }$ & \\
\hline
\end{tabular}

Tabel IV.3. Data hasil unjuk kerja alat terhadap gangguan arus lebih pada ketiga fasa 
Jurnal Qua Teknika, Vol. 6 No. 1 Maret 2016

p ISSN: 2088 2424; e -ISSN: 2527 3892

UNISBA Blitar, Http://qua.unisbablitar.ejournal.web.id

M. Nur Rois Zain. 2016. Sistem Pengaman Pendingin Udara Tiga Fasa Otomatis dalam Mengantisipasi Gangguan. Jurnal Qua Teknika, (2016), 6(1):1 15.

\begin{tabular}{|c|c|c|c|c|c|}
\hline \multirow[t]{2}{*}{ Beban (A) } & \multicolumn{3}{|c|}{$\begin{array}{c}\text { Arus lebih }(A) \\
(25 \% \text { arus beban) }\end{array}$} & \multicolumn{2}{|c|}{ Kondisi } \\
\hline & Fasa R & Fasa S & Fasa T & Kerja & Tidak \\
\hline 0.89 & 0.22 & 0.22 & 0.22 & $\checkmark$ & \\
\hline 1.27 & 0,32 & 0,32 & 0,32 & $\sqrt{ }$ & \\
\hline 1.73 & 0,43 & 0,43 & 0.43 & $\sqrt{ }$ & \\
\hline 2.1 & 0.53 & 0.53 & 0.53 & $\checkmark$ & \\
\hline 0,89 & 0.22 & 0,22 & 0,22 & $\sqrt{ }$ & \\
\hline 1,27 & 0,32 & 0.32 & 0,32 & $\sqrt{ }$ & \\
\hline 1.73 & 0,43 & 0.43 & 0.43 & $\sqrt{ }$ & \\
\hline 2.1 & 0.53 & 0.53 & 0.53 & $\sqrt{ }$ & \\
\hline 0.89 & 0,22 & 0,22 & 0,22 & $\sqrt{ }$ & \\
\hline 1,27 & 0,32 & 0,32 & 0,32 & $\sqrt{ }$ & \\
\hline 1.73 & 0.43 & 0.43 & 0.43 & $\sqrt{ }$ & \\
\hline 2.1 & 0.53 & 0.53 & 0.53 & $\sqrt{ }$ & \\
\hline
\end{tabular}

\section{Gangguan tegangan lebih (overvoltage fault)}

Variasi tegangan line yang masih diperbolehkan harus kurang 10\%, selebihnya sudah merupakan gangguan dan harus diproteksi (Andrew D. Thouse 1975:259). Berdasarkan pernyataan diatas, tegangan lebih yang harus diamankan adalah $110 \%$ tegangan line normal, yaitu $220 \times 1,1=242$ volt. Apabila variasi tegangan $+10 \%$ maka arus motor beban penuh akan turun 7\% (Handbook of AC system design 1965:847). Percobaan gangguan tegangan lebih dilakukan dengan memberikan pengurangan arus pada fasa terganggu sebesar $7 \%$. Data hasil percobaan ditunjukkan pada tabel berikut.

Tabel IV.4. Data hasil unjuk kerja alat terhadap gangguan tegangan lebih 
Jurnal Qua Teknika, Vol. 6 No. 1 Maret 2016

p ISSN: 2088 2424; e -ISSN: 2527 3892

UNISBA Blitar, Http://qua.unisbablitar.ejournal.web.id

M. Nur Rois Zain. 2016. Sistem Pengaman Pendingin Udara Tiga Fasa Otomatis dalam Mengantisipasi Gangguan. Jurnal Qua Teknika, (2016), 6(1):1 15.

\begin{tabular}{|c|c|c|c|c|c|c|c|c|}
\hline \multirow{2}{*}{ Bebas (A) } & \multicolumn{3}{|c|}{ Tegangan line $(\mathbf{V})$} & \multicolumn{3}{|c|}{ Arus Behan (A) } & \multicolumn{2}{|c|}{ Konstisi } \\
\hline & Fasa $R$ & Fasa S & Fana I & Fasa R & Fanas & Fasa T & Kerja & Tidal \\
\hline 0,89 & 242 & 220 & 220 & 0.83 & 0.89 & 0,39 & $\checkmark$ & \\
\hline 1.27 & 242 & 220 & 220 & 1,18 & 1,27 & 1.27 & $\checkmark$ & \\
\hline 1,73 & 242 & 220 & 220 & 1.6 & 1.73 & 1,73 & $\checkmark$ & \\
\hline 2.1 & 242 & 220 & 220 & 1.95 & 2,1 & 2.1 & $\downarrow$ & \\
\hline 0,89 & 220 & 242 & 220 & 0.89 & 0.83 & 0.89 & $\checkmark$ & \\
\hline 1,27 & 220 & 242 & 220 & 1.27 & 1,18 & 1,27 & $\checkmark$ & \\
\hline 1,73 & 220 & 242 & 220 & 1,73 & 1.6 & 1,73 & $\checkmark$ & \\
\hline 2,1 & 220 & 242 & 220 & 2.1 & 1.95 & 2,1 & $\sqrt{ }$ & \\
\hline 0,89 & 220 & 220 & 242 & 0,89 & 0.89 & 0,83 & $\sqrt{ }$ & \\
\hline 1.27 & 220 & 220 & 242 & 1,27 & 1,27 & 1.18 & $\checkmark$ & \\
\hline 1,73 & 220 & 220 & 242 & 1,73 & 1.73 & 1.6 & $\checkmark$ & \\
\hline 2.1 & 220 & 220 & 242 & 2,1 & 2.1 & 1.95 & $\checkmark$ & \\
\hline
\end{tabular}

\section{Gangguan tegangan kurang (undervoltage fault)}

Toleransi variasi tegangan kurang harus dibawah 10\%, tegangan turun 10\% dan lebih dari itu harus diproteksi. Penurunan tegangan $10 \%$ menyebabkan arus motor beban penuh naik $11 \%$ (Handbook of AC system design 1965:847). Tegangan line minimal yang harus diproteksi adalah $220 \times 0,9=198$ volt. Percobaan gangguan tegangan kurang dilakukan dengan memberikan penambahan arus pada fasa terganggu sebesar $11 \%$. Data hasil percobaan ditunjukkan pada tabel berikut.

\section{Tabel IV.5. Data hasil unjuk kerja alat terhadap gangguan tegangan kurang}


Jurnal Qua Teknika, Vol. 6 No. 1 Maret 2016

p ISSN: 2088 2424; e ISSN: 2527 3892

UNISBA Blitar, Http: / qua.unisbablitar.ejournal.web.id

M. Nur Rois Zain. 2016. Sistem Pengaman Pendingin Udara Tiga Fasa Otomatis dalam Mengantisipasi Gangguan. Jurnal Qua Teknika, (2016), 6(1):1 15.

\begin{tabular}{|c|c|c|c|c|c|c|c|c|}
\hline \multirow{2}{*}{ Beban (A) } & \multicolumn{3}{|c|}{ Trzangab flue (V) } & \multicolumn{3}{|c|}{ Arus Heban (A) } & \multicolumn{2}{|c|}{ Kendisi } \\
\hline & Fasa h & Fatas & Fasa I & Fasa R & Favas & Fasa I & Kerja & Tidal: \\
\hline 0.89 & 198 & 220 & 220 & 0,95 & 0.89 & 0.89 & $\sqrt{ }$ & \\
\hline 1.27 & 198 & 220 & 220 & 1.40 & 1.27 & 1.27 & $\checkmark$ & \\
\hline 1,73 & 198 & 220 & 220 & 192 & 1,73 & 1.73 & $\checkmark$ & \\
\hline 2,1 & 198 & 220 & 230 & 2,33 & 2.1 & 2,1 & $\sqrt{ }$ & \\
\hline 0,89 & 220 & 195 & 220 & 0,89 & 0,95 & 0,89 & $\gamma$ & \\
\hline 1.27 & 220 & 198 & 220 & 1.27 & 1.40 & 1.27 & $\sqrt{ }$ & \\
\hline 1.73 & 220 & 198 & 230 & 1,73 & 1.92 & 1,73 & $\checkmark$ & \\
\hline 2,1 & 220 & 198 & 220 & 2.1 & 2.33 & $2 . \mathrm{I}$ & $\gamma$ & \\
\hline 0.89 & 220 & 220 & 198 & 0.89 & 0.89 & 0,95 & $\sqrt{ }$ & \\
\hline 1.27 & 220 & 220 & 198 & 1.27 & 1.27 & 1,40 & $\checkmark$ & \\
\hline 1.73 & 220 & 220 & 198 & 1.73 & 1.73 & 1.92 & $\checkmark$ & \\
\hline 2,1 & 220 & 220 & 198 & 2,1 & 2,1 & 2,33 & $\sqrt{ }$ & \\
\hline
\end{tabular}

\section{Gangguan kegagalan fasa (phase failure)}

Percobaan dilakukan dengan memberikan gangguan putus saluran salah satu fasa. Pengukuran dilakukan pada sistem tegangan tiga fasa 220 / 380 volt. Beban terpasang saat pengukuran adalah beban seimbang 0,89 ampere, 1,27 ampere, 1,73 ampere dan 2,1 ampere. Setelah dilakukan percobaan, maka hasil percobaan dicatat. Data hasil percobaan ditunjukkan pada tabel IV.6.

\section{Gangguan Fasa Terbalik (reversing of phase)}

Percobaan dilakukan dengan membalik urutan fasa ke beban, dari urutan fasa normal $R$ - S - T. Pengukuran dilakukan pada sistem tegangan tiga fasa 220 / 380 volt. Beban terpasang saat pengukuran adalah beban seimbang 0,89 ampere, 1,27 ampere, 1,73 ampere dan 2,1 ampere untuk tiap pengukuran. Berikut ini pada tabel 9 ditunjukkan unjuk kerja alat terhadap gangguan fasa terbalik.

Tabel IV.6. Data hasil unjuk kerja alat terhadap gangguan kegagalan fasa 
Jurnal Qua Teknika, Vol. 6 No. 1 Maret 2016

p ISSN: 2088 2424; e -ISSN: 2527 3892

UNISBA Blitar, Http://qua.unisbablitar.ejournal.web.id

M. Nur Rois Zain. 2016. Sistem Pengaman Pendingin Udara Tiga Fasa Otomatis dalam Mengantisipasi Gangguan. Jurnal Qua Teknika, (2016), 6(1):1 15.

\begin{tabular}{|c|c|c|c|c|}
\hline \multicolumn{3}{|c|}{ Arus Beban (A) } & \multicolumn{2}{c|}{ Kondisi } \\
\hline Fasa R & Fasa S & Fasa T & Kerja & Tidak \\
\hline Fasa putus & 0,89 & 0,89 & $\sqrt{ }$ & \\
\hline Fasa putus & 1,27 & 1,27 & $\sqrt{ }$ & \\
\hline Fasa putus & 1,73 & 1,73 & $\sqrt{ }$ & \\
\hline Fasa putus & 2,1 & 2,1 & $\sqrt{ }$ & \\
\hline 0,89 & Fasa putus & 0,89 & $\sqrt{ }$ & \\
\hline 1,27 & Fasa putus & 1,27 & $\sqrt{ }$ & \\
\hline 1,73 & Fasa putus & 1,73 & $\sqrt{ }$ & \\
\hline 2,1 & Fasa putus & 2,1 & $\sqrt{ }$ & \\
\hline 0,89 & 0,89 & Fasa putus & $\sqrt{ }$ & \\
\hline 1,27 & 1,27 & Fasa putus & Fasa putus & $\sqrt{ }$ \\
\hline 1,73 & 1,73 & Fasa putus & $\sqrt{ }$ & \\
\hline 2,1 & 2,1 & keria alat terhadan & \\
\hline
\end{tabular}

Tabel IV.7. Data hasil unjuk kerja alat terhadap gangguan fasa terbalik

\begin{tabular}{|c|c|c|}
\hline \multirow{2}{*}{ Urutan Fasa } & \multicolumn{2}{|c|}{ Kondisi } \\
\hline & Kerja & Tidak \\
\hline R-S-T & & $\sqrt{ }$ \\
\hline S-R-T & $\sqrt{ }$ & \\
\hline R-T-S & $\sqrt{ }$ & \\
\hline T-S-R & $\sqrt{ }$ & \\
\hline S-T-R & & \\
\hline T-R-S & & \\
\hline
\end{tabular}

\section{Respon waktu alat pengaman}

\section{a. Overload protection}

Percobaan dilakukan dengan memberikan variasi arus pada beban tetap. Pengukuran dilakukan pada tegangan tiga fasa 220 / 380 volt. Setelah dilakukan pengukuran sebanyak lima kali untuk setiap pengukuran, maka hasil pengukuran tersebut dicatat dalam tabel, seperti ditunjukkan pada lampiran. Berikut ini pada tabel 10 ditunjukkan nilai reratanya

Tabel IV.8. Rerata respon waktu alat pengaman terhadap beban lebih 
Jurnal Qua Teknika, Vol. 6 No. 1 Maret 2016

p ISSN: 2088 2424; e -ISSN: 2527 3892

UNISBA Blitar, Http:// qua.unisbablitar.ejournal.web.id

M. Nur Rois Zain. 2016. Sistem Pengaman Pendingin Udara Tiga Fasa Otomatis dalam Mengantisipasi Gangguan. Jurnal Qua Teknika, (2016), 6(1):1 15.

\begin{tabular}{|c|c|}
\hline $\begin{array}{c}\text { Prosentase variasi } \\
\text { Beban lebih } \\
(\%)\end{array}$ & $\begin{array}{c}\text { Respon waktu } \\
\text { (ms) }\end{array}$ \\
\hline 7 & 409 \\
\hline 9 & 381 \\
\hline 18 & 221 \\
\hline 23 & 82 \\
\hline 36 & 53 \\
\hline
\end{tabular}

\section{b. Overvoltage protection}

Percobaan dilakukan dengan memberikan pengurangan arus sebesar $7 \%$ dari arus beban. Pengukuran dilakukan pada tegangan tiga fasa 220 / 380 volt. Setelah dilakukan pengukuran sebanyak lima kali untuk setiap pengukuran, maka hasil pengukuran tersebut dicatat dalam tabel, seperti ditunjukkan pada lampiran. Berikut ini pada tabel IV.9 ditunjukkan nilai reratanya.

Tabel IV.9. Rerata respon waktu alat pengaman terhadap over voltage

\begin{tabular}{|c|c|c|}
\hline Beban & Tegangan naik 10\% & $\begin{array}{c}\text { Respon waktu } \\
\text { (ms) }\end{array}$ \\
\hline 0,89 & 242 & 422 \\
\hline 1,27 & 242 & 407 \\
\hline 1,73 & 242 & 402 \\
\hline 2,1 & 242 & 397 \\
\hline
\end{tabular}

\section{c. Undervoltage protection}

Percobaan dilakukan dengan memberikan penambahan arus sebesar \% dari arus beban. Pengukuran dilakukan pada tegangan tiga fasa 220 / 380 volt. Setelah dilakukan pengukuran sebanyak lima kali untuk setiap pengukuran, maka hasil pengukuran tersebut dicatat dalam tabel, seperti ditunjukkan pada lampiran. Berikut ini pada tabel IV.10 ditunjukkan nilai reratanya.

Tabel IV.10. Rerata respon waktu alat pengaman terhadap under voltage 
Jurnal Qua Teknika, Vol. 6 No. 1 Maret 2016

p -ISSN: 2088 2424; e -ISSN: 2527 3892

UNISBA Blitar, Http://qua.unisbablitar.ejournal.web.id

M. Nur Rois Zain. 2016. Sistem Pengaman Pendingin Udara Tiga Fasa Otomatis dalam Mengantisipasi Gangguan. Jurnal Qua Teknika, (2016), 6(1):1 15.

\begin{tabular}{|c|c|c|}
\hline Beban & Tegangan turun 10\% & $\begin{array}{c}\text { Respon waktu } \\
\text { (ms) }\end{array}$ \\
\hline 0,89 & 198 & 312 \\
\hline 1,27 & 198 & 308 \\
\hline 1,73 & 198 & 294 \\
\hline 2,1 & 198 & 288 \\
\hline
\end{tabular}

\section{d. Phase failure protection}

Percobaan dilakukan dengan memberikan gangguan putus saluran salah satu fasa. Pengukuran dilakukan pada sistem tegangan tiga fasa 220 / 380 volt. Beban terpasang saat pengukuran adalah beban seimbang 0,89 ampere, 1,27 ampere, 1,73 ampere dan 2,1 ampere. Setelah dilakukan percobaan, maka hasil percobaan dicatat.

Data hasil percobaan ditunjukkan pada tabel IV.11.

Tabel IV.11. Rerata respon waktu alat pengaman terhadap gangguan kegagalan fasa

\begin{tabular}{|c|c|c|}
\hline Beban & Fasa R/S/T & $\begin{array}{c}\text { Respon waktu } \\
\text { (ms) }\end{array}$ \\
\hline 0,89 & Putus & 42 \\
\hline 1,27 & Putus & 37 \\
\hline 1,73 & Putus & 32 \\
\hline 2,1 & Putus & 26 \\
\hline
\end{tabular}

Berdasarkan kajian teoritik, diharapkan alat akan bekerja jika terjadi gangguan berupa arus lebih, tegangan lebih, tegangan kurang, kegagalan fasa, fasa terbalik.

\section{Gangguan arus lebih}

Sebuah pengaman arus lebih harus dapat menjamin tidak memutuskan suplai ke beban bila arus yang mengalir masih berada pada kondisi normal, tetapi pengaman harus mampu mengamankan atau memutus suplai apabila arus yang mengalir sudah naik melebihi $25 \%$ (Andrew D. Thouse 1975:259) Dari hasil pengujian seperti terlihat pada tabel IV.1, IV.2, dan IV.3 menunjukan bahwa alat mampu melindungi beban dari gangguan arus lebih dengan kenaikan $25 \%$ dari beban terpasang. Gangguan arus lebih menyebabkan arus pada fasa yang terganggu menjadi naik, alat mendeteksi adanya kenaikan arus yang melebihi batas setting alat pengaman, sehingga alat akan memproteksi.

\section{Gangguan tegangan lebih (overvoltage fault)}


Jurnal Qua Teknika, Vol. 6 No. 1 Maret 2016

p ISSN: 2088 2424; e ISSN: 2527 3892

UNISBA Blitar, Http:// qua.unisbablitar.ejournal.web.id

M. Nur Rois Zain. 2016. Sistem Pengaman Pendingin Udara Tiga Fasa Otomatis dalam Mengantisipasi

Gangguan. Jurnal Qua Teknika, (2016), 6(1):1 15.

Perubahan tegangan line pada motor induksi mempengaruhi perubahan arus beban (Handbook of AC system design 1965:846). Pada air conditioning motor kompresor harus selalu dijaga pada kondisi beban penuh, peningkatan tegangan line akan menyebabkan arus motor beban penuh mengalami penurunan. Variasi tegangan line yang masih diperbolehkan harus kurang 10\%, selebihnya sudah merupakan gangguan dan harus diproteksi (Andrew D. Thouse 1975:259). Kenaikan tegangan mulai 10\% dari tegangan kerja harus segera diproteksi karena arus beban penuh pada motor kompresor air conditioning akan turun sebesar 7\%. Dengan penurunan arus sebesar ini akan menyebabkan beban menjadi tidak terjaga pada beban penuh sehingga tekanan refrigerant akan berubah seiring dengan perubahan beban tersebut. Keadaan ini akan merusak sistem kerja air conditioning, karena bila tekanan refrigerant tidak sesuai dengan ketentuan maka sistem menjadi tidak berfungsi. Alat pengaman diberi penurunan arus sebesar $7 \%$ dari arus beban penuh mampu memproteksi beban, sehingga alat mampu pula memproteksi tegangan yang naik sebesar $10 \%$ dari tegangan kerja.

\section{Gangguan tegangan kurang (undervoltage fault)}

Petir, gangguan hubung singkat dan gangguan arus lebih merupakan penyebab terjadinya gangguan tegangan kurang. Gangguan tegangan kurang dapat bersifat sementara dan juga bisa permanen tergantung penyebabnya. Dip tegangan kurang dari $10 \%$ dan variasi frekwensi kurang dari 5\% masih diperbolehkan, jika variasi yang melebihi ketentuan diatas akan memungkinkan motor kompresor menjadi overheat sehingga menyebabkan motor tersebut berhenti (Handbook of AC system design 1965:842). Variasi tegangan line yang masih diperbolehkan harus kurang 10\%, selebihnya sudah merupakan gangguan dan harus diproteksi (Andrew D. Thouse 1975:259) Berdasarkan pernyataan diatas, alat pengaman tegangan kurang harus mampu memproteksi beban bila tegangan kerja turun 10\%. Bila tegangan kerja turun $10 \%$ maka arus motor beban penuh akan naik sebesar $11 \%$ (Handbook of AC system design 1965:847). Pada percobaan alat diberi kenaikan arus beban penuh sebesar $11 \%$ dan berdasarkan tabel IV.5 alat mampu memproteksi beban. Jadi apabila tegangan kerja turun sebesar $10 \%$ alat mampu memproteksi beban.

\section{Gangguan kegagalan fasa (phase failure fault)}

Kegagalan fasa pada sistem tenaga listrik fasa banyak harus dicegah. Kegagalan fasa mungkin terjadi karena seting peralatan dalam keadaan yang berbeda - beda, sekring pada line power suply atau pada branch circuit putus, kegagalan pada salah satu kontak atau line rusak (Handbook of AC system design 1965:842). Berdasarkan tabel IV.6. alat pengaman mampu memproteksi beban jika terjadi kegagalan fasa, arus pada fasa yang terjadi kegagalan adalah nol, sensor membaca arus yang tidak sama dengan fasa yang lain sehingga alat akan memproteksi. Pengaman ini mendeteksi ketidakseimbangan arus yang mengalir, terputusnya salah satu fasa menyebabkan arus pada saluran terganggu sama dengan nol. Dengan kata lain sistem tidak seimbang lagi. Pengujian ini bertujuan untuk mengetahui apakah alat akan bekerja jika salah satu fasanya terputus.

\section{Gangguan fasa terbalik (reversing of phase)}


Fasa yang terbalik akan membuat arah putaran dari motor kompresor akan berbalik arah, hal ini akan menyebabkan aliran refrigerant juga berubah. (Handbook of AC system design 1965:842). Berdasarkan tabel IV.7, alat mampu memproteksi beban yang mendapat catu daya yang terbalik fasanya. Alat mampu memproteksi beban bila beban mendapat catu daya dengan urutan S-R-T, T-S-R, R-T-S. Alat akan terus memproteksi bila beban masih mendapatkan catu daya dengan urutan terbalik, apabila urutan telah sesuai maka dalam selang waktu 24 detik alat akan kembali ke posisi normal.

\section{Respon waktu alat pengaman}

Pasal 316.A.1 PUIL 1987 menambahkan bahwa pengaman pendeteksi kebocoran arus akibat kegagalan isolasi, harus dapat memutuskan rangkaian dalam waktu tidak lebih dari 0,2 detik. Respon waktu untuk masing - masing gangguan sangat dipengaruhi oleh konstanta waktu pengisian kapasitor pada rangkaian penyearah (gambar II.19). Perubahan arus memberikan pengaruh pada keluaran trafo arus dengan respon waktu yang sangat cepat. Perubahan masukan pada rangkaian penyearah (gambar II.19) tidak menyebabkan perubahan dengan cepat pada keluarannya. Kapasitor masih menyimpan energi pada saat terjadi penurunan tegangan masukan. Saat salah satu fasa terputus, maka keluaran dari trafo arus sama dengan nol. Saat masukan rangkaian penyearah dengan cepat berubah menjadi nol, maka keluaran rangkaian secara perlahan menjadi nol. Dari hasil pengujian menunjukan bahwa sensitifitas alat ditunjukkan seperti pada grafik IV.1, IV.2, IV.3, dan IV.4.

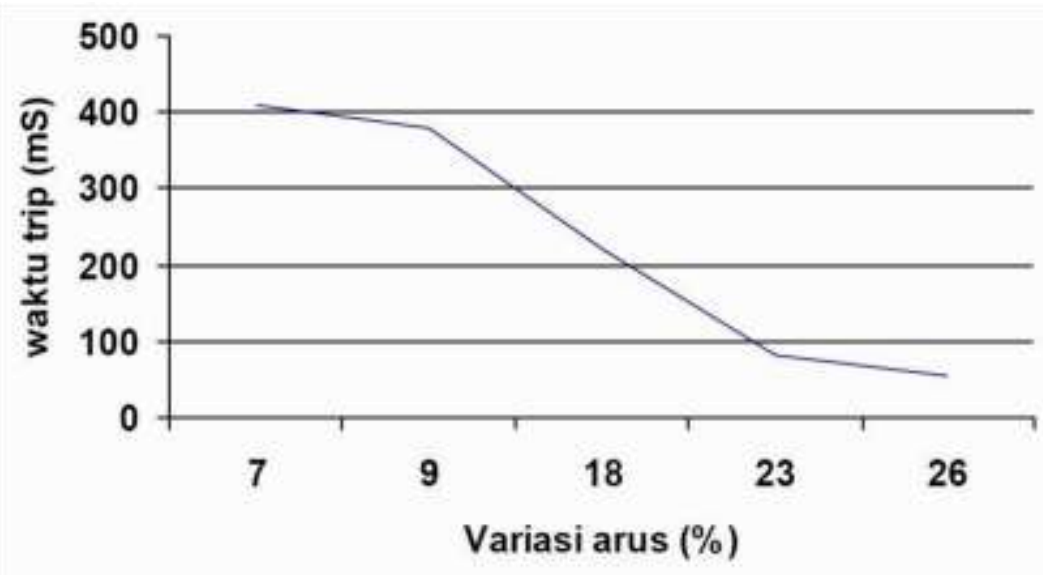

Grafik IV.1. Respon waktu alat terhadap beban lebih 
Jurnal Qua Teknika, Vol. 6 No. 1 Maret 2016

p ISSN: 2088 2424; e-ISSN: 2527 3892

UNISBA Blitar, Http://qua.unisbablitar.ejournal.web.id

M. Nur Rois Zain. 2016. Sistem Pengaman Pendingin Udara Tiga Fasa Otomatis dalam Mengantisipasi Gangguan. Jurnal Qua Teknika, (2016), 6(1):1 15.

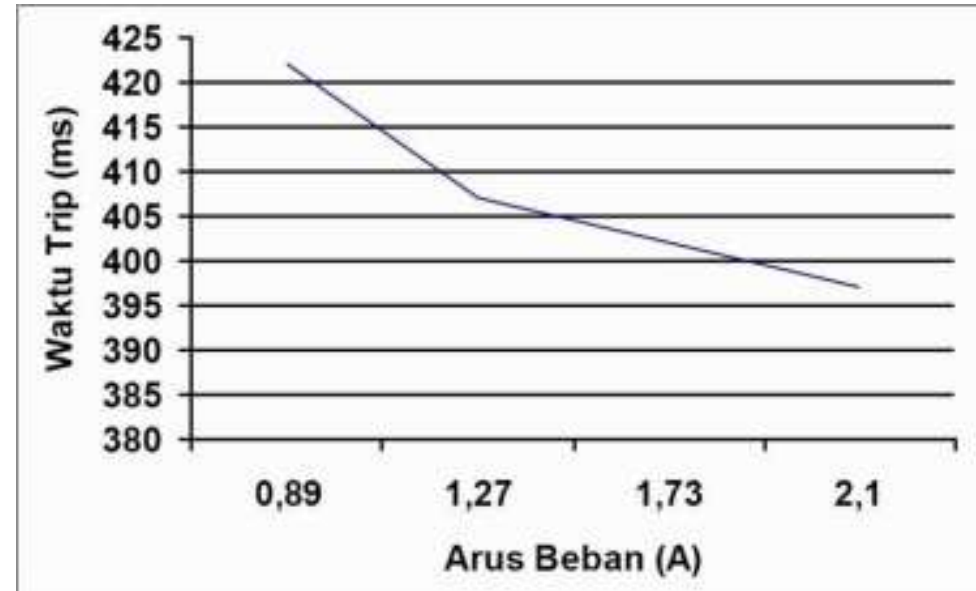

Grafik IV.2. Respon waktu alat terhadap tegangan line naik $10 \%$

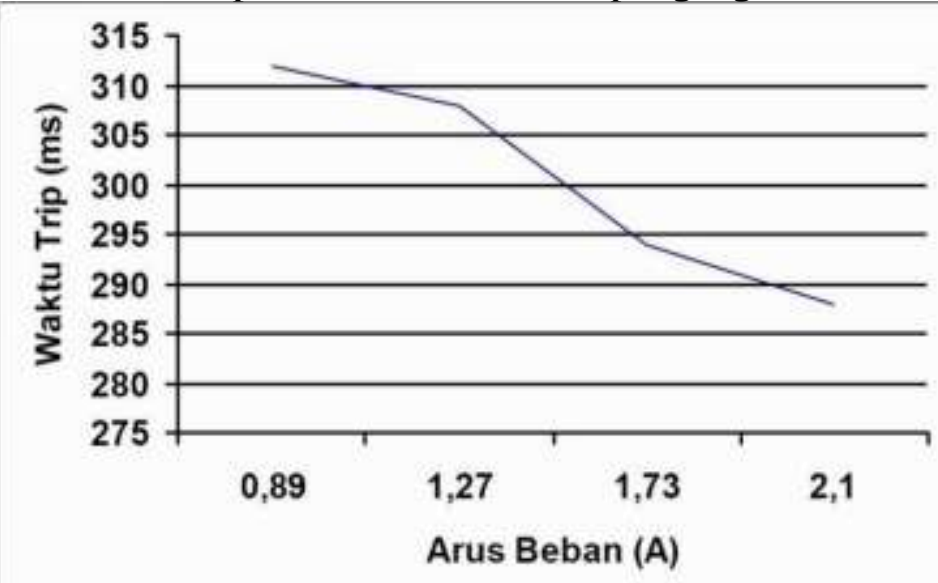

Grafik IV.3. Respon waktu alat terhadap tegangan line turun $10 \%$

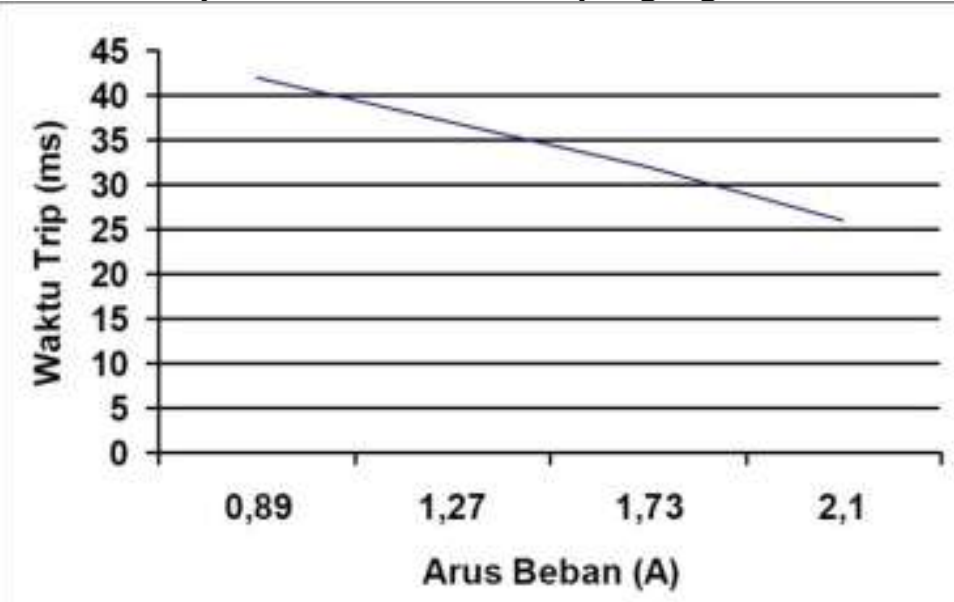

Grafik IV.4. Respon waktu alat terhadap kegagalan fasa

\section{KESIMPULAN DAN SARAN}

\subsection{Kesimpulan}


Dari hasil pengamatan dan data yang diperoleh sesuai tujuan yang telah dirumuskan, dapat disimpulkan

1. Alat pengaman air conditioning tiga fasa akan bekerja jika terjadi :

a. Gangguan beban lebih (over load).

b. Gangguan tegangan lebih (over voltage).

c. Gangguan tegangan kurang (under voltage).

d. Gangguan kegagalan fasa (phase failure).

e. Gangguan fasa terbalik (reversing of phase).

2. Tingkat kepekaan alat dalam bekerja memutus tegangan sumber adalah :

a. Untuk gangguan beban lebih $25 \%=82 \mathrm{~ms}$ b Untuk gangguan tegangan lebih $10 \%=407 \mathrm{~ms}$.

c.Untuk gangguan tegangan kurang $10 \%=300,5 \mathrm{~ms}$.

d.Untuk gangguan kegagalan fasa $=34,25 \mathrm{~ms}$.

\subsection{Keterbatasan Alat}

Berdasarkan deskripsi data dan penjelasan dapat disimpulkan beberapa keterbatasan alat, antara lain :

1. Alat tidak bisa digunakan pada jaringan dengan KVA beban yang berubah ubah lebih dari $10 \%$.

2. Tidak adanya perlindungan pada masukan rangkaian pembanding terhadap lonjakan tegangan.

\subsection{Implikasi}

Pengaman air conditioning tiga fasa secara elektronis, memberikan manfaat untuk mengamankan air conditioning dari kondisi sistem yang tidak layak pakai. Dengan menggunakan satu alat pengaman sudah dapat memproteksi dari lima kondisi gangguan yang dapat membahayakan air conditioning. Selama ini pengaman air conditioning didesain secara terpisah sesuai jenis gangguan. Hal ini menunjukkan adanya efisiensi pada sistem proteksi, khususnya dunia industri.

Hasil penelitian dengan karya nyata sebuah pengaman padat memberikan tambahan kajian dalam dunia pendidikan khususnya pada kajian sistem proteksi. Kaitannya dengan menambah wawasan dalam dunia pendidikan.

\subsection{Saran}

Diharapkan bagi para pembaca dapat menyempurnakan alat ini dengan memperbaiki respon waktu kerja. Respon kerja alat pengaman ini sangat dipengaruhi oleh sistem konversi arus bolak - balik ke tegangan searah.

Pengaman op-amp terhadap lonjakan tegangan masukan yang terlampau besar dapat dilakukan dengan merancang kapasitor pada terminal masukan op - amp.

Ketelitian alat dapat ditingkatkan dengan memperkuat rangkaian pembanding. Untuk dapat mengatasi keseimbangan alat sebaiknya op - amp komponen dengan toleransi yang lebih kecil dan gunakan op - amp dengan pengaturan offset nul. 
Jurnal Qua Teknika, Vol. 6 No. 1 Maret 2016

p ISSN: 2088 2424; e ISSN: 2527 3892

UNISBA Blitar, Http:// qua.unisbablitar.ejournal.web.id

M. Nur Rois Zain. 2016. Sistem Pengaman Pendingin Udara Tiga Fasa Otomatis dalam Mengantisipasi Gangguan. Jurnal Qua Teknika, (2016), 6(1):1 15.

\section{DAFTAR PUSTAKA}

Althouse D. Andrew, 1975. Modern Refrigeration and Air Conditioning. South Holland : The Goodheart-willcox company, inc.

Coughlin, Robert.F, dan Driscoll, Frederick.F. 1985. Penguat Operasional dan rangkaian Terpadu Linier, Jakarta : Erlangga.

Kenneth C. S., 1987. Microelectronic Circuit. Toronto : CBS College.

Malvino, dan Donald P. Leach, 1992. Alih Bahasa : Irwan Wijaya. Prinsip-Prinsip Dan

Penerapan Digital.

Jakarta : Erlangga.

Marston,R.M., 1989. Op-Amp and OTA Circuits Manual. Thowbridge : NEWNES.

Millman, Jacob, Ph. D, 1993. MikroElektronika, Sistem Digital dan rangkaian Analog.

Terjemahan : Ir.

Sutanto, M.Sc. Jakarta : Erlangga.

Sunomo, 1992. Elektronika II. Yogyakarta : IKIP Yogyakarta

Sulasno, 1993. Analisa Sistem Tenaga Listrik. Semarang : Satya Wacana.

Wasito, S. 1996. Data Sheet Book I, Jakarta : Gramedia.

William D. Stevenson, 1982. Elements of Power System Analysis. (Erlangga. Terjemahan).

Karolina : McGraw-Hill, Inc. , 1965. Handbook of Air Conditioning System Design. Newyork : McGraw-Hill

Book Company. 1996. Data dan Persamaan Transistor. Jakarta : PT Elex Media Komputindo. 1985. Data Sheet Book I. Netherlands : Elektuur. 1999. Katalog Produk 1999 - 2000. : PT. Schneider Indonesia. , 1987. Peraturan Umum Instalasi Listrik. Jakarta : LIPI. 